\title{
Evaluation of bioaugmentation and biostimulation on arsenic remediation in soil through biovolatilization
}

\author{
Peng Chen ${ }^{1,2} \cdot \mathrm{Jin} \mathrm{Li}^{1,3} \cdot$ Hong-Yan Wang ${ }^{1} \cdot$ Rui-Lun Zheng ${ }^{4} \cdot$ Guo-Xin Sun ${ }^{1}$
}

Received: 8 February 2017 / Accepted: 24 July 2017 / Published online: 1 August 2017

(C) Springer-Verlag GmbH Germany 2017

\begin{abstract}
Arsenic (As) removal through microbially driven biovolatilization can be explored as a potential method for As bioremediation. However, its effectiveness needs to be improved. Biostimulation with organic matter amendment and bioaugmentation with the inoculation of genetic engineered bacteria could be potential strategies for As removal and site remediation. Here, the experiments were conducted to evaluate the impacts of rice straw and biochar amendment, inoculation of genetic engineered Pseudomonas putida KT2440 (GE P. putida) with high As volatilization activity, on microbial mediated As volatilization and removal from three different arseniferous soils. In general, the addition of rice straw (5\%) significantly enhanced As methylation and volatilization in comparison with corresponding nonamended soils. Biochar amendments and inoculation of the GE P. putida increased As methylation and volatilization, respectively, but less than that of rice straw addition. The effectiveness of As volatilizations are quite different in the various paddy soils. The combined amendments of rice straw and GE
\end{abstract}

Responsible editor: Elena Maestri

Guo-Xin Sun

gxsun@rcees.ac.cn

1 State Key Laboratory of Urban and Regional Ecology, Research Center for Eco-Environmental Sciences, Chinese Academy of Sciences, Beijing 100085, People's Republic of China

2 University of Chinese Academy of Sciences, Beijing 100049, People's Republic of China

3 College of Resources and Environment, Yunnan Agricultural University, Kunming 650201, People's Republic of China

4 Research and Development Center for Grasses and Environment, Beijing Academy of Agriculture and Forestry Sciences, Beijing 100097, People's Republic of China
P. putida exhibited the highest As removal efficiency $(483.2 \mu \mathrm{g} / \mathrm{kg} /$ year $)$ in Dayu soil, with $1.2 \%$ volatilization of the total As annually. The highest water-soluble As concentration $(0.73 \mathrm{mg} / \mathrm{kg})$ in this soil could be responsible for highest As volatilization besides the rice straw and bacteria in this soil.

Keywords Arsenic $\cdot$ Remediation $\cdot$ Biovolatilization . Biostimulation · Bioaugmentation · Genetic engineered Pseudomonas putida KT2440

\section{Introduction}

Arsenic is ranked first on the Super Fund List of Hazardous Substances by the US Environmental Protection Agency (http://www.atsdr.cdc.gov/SPL/index.html). Its mobility and toxicity vary greatly among different chemical species. Inorganic arsenate $(\mathrm{As}(\mathrm{V}))$ and arsenite (As(III)) are highly toxic in the natural environment (Gong et al. 2002; Akter et al. 2005; Wang et al. 2014a). Transformations of As species in soil usually involve oxidation, reduction, and methylation. The intermediate products of biomethylation are pentavalent methylated arsenicals and trivalent methylated arsenicals. The former include monomethylarsonic acid $(\operatorname{MMAs}(\mathrm{V}))$, dimethylarsinic acid $(\operatorname{DMAs}(\mathrm{V}))$, and trimethylarsine oxide $(\operatorname{TMAs}(\mathrm{V}) \mathrm{O})$, which have low toxicities with $\mathrm{LD}_{50}$ of 1800,1200 , and $10,000 \mathrm{mg} / \mathrm{kg}$, respectively (Feldmann et al. 2004). These trivalent methylated arsenical intermediates, monomethylarsonous acid (MMAs(III)) and dimethylarsinous acid (DMAs(III)), are highly toxic, but they could be easily oxidized to less toxic $\operatorname{MMAs}(\mathrm{V})$ and $\operatorname{DMAs}(\mathrm{V})$. So, methylated As were supposed to be harmless to human. Arsenic transformations are commonly driven by microbes in soil (Bentley and Chasteen 2002; Rhine et al. 2005; Liao et al. 2011). Several studies stated that As can 
be volatilized from soil into the atmosphere by microorganisms such as fungi, yeast, and bacteria (Cullen and Reimer 1989; Thomas and Rhue 1997; Turpeinen and Pantsar 2002; Meyer et al. 2007; Zheng et al. 2013; Wang et al. 2014a, b, 2015). This process involves sequential conversion of the inorganic As into arsines, including monomethylarsine $\left(\mathrm{AsH}_{2}\left(\mathrm{CH}_{3}\right)\right)$, dimethylarsine $\left(\mathrm{AsH}\left(\mathrm{CH}_{3}\right)_{2}\right)$, trimethylarsine $\left(\mathrm{As}\left(\mathrm{CH}_{3}\right)_{3}\right)$, and $\mathrm{AsH}_{3}$ (Bentley and Chasteen 2002; Turpeinen and Pantsar 2002; Qin et al. 2006). Microbial biomethylation of arsenic is believed to be an activation mechanism (Challenger 1945; Cullen and Bentley 2005). The final product of the methylation is volatile $\mathrm{As}\left(\mathrm{CH}_{3}\right)_{3}$, which is non-toxic $\left(\mathrm{LD}_{50} 1060 \mathrm{mg} / \mathrm{L}\right)$ (Cullen and Bentley 2005). The values of $\mathrm{LD}_{50}$ for dimethylarsine and arsine were 6 and $0.2-1.6 \mathrm{mg} / \mathrm{L}$, respectively (Cullen and Bentley 2005), and $\mathrm{AsH}_{2}\left(\mathrm{CH}_{3}\right)$ and $\mathrm{AsH}\left(\mathrm{CH}_{3}\right)_{2}$ were identified to be potent genotoxic (Mestrot et al. 2013). Considering the dilution effect of air and relatively short halflives of arsines (about $8 \mathrm{~h}$ ) (Mestrot et al. 2011b), the release of these volatilized As into atmosphere would not significantly increase their level and would not be harmful to organisms.

The cost-effective in situ biovolatilization of As from contaminated soil may be an alternative for bioremediation technologies (Brown et al. 2003; Hartley et al. 2009). The As removal from arseniferous soil via biological volatilization has only been explored preliminarily (Wang et al. 2014a). However, the amounts of volatile As generated by indigenous microorganisms were limited and the rates of As volatilization were relatively low (Wang et al. 2014a). It is imperative to explore ways to accelerate the rate of in situ volatilization of As for remediation of As-contaminated soil. It has been reported that As methylation and volatilization in soil is a strictly biological process and driven by microbial activity (Turpeinen and Pantsar 2002; Zheng et al. 2013; Wang et al. 2014a, b). The rate and efficiency of As methylation and volatilization can be enhanced through biostimulation and/or bioaugmentation (Wang et al. 2014a). Biostimulation aims at enhancing microbial activities to remove As through methylation and volatilization driven by indigenous microorganisms in the site (Gao and Burau 1997). Bioaugmentation is to improve As remediation by inoculating microorganisms with high activities of As volatilization (Edvantoro et al. 2004; Wang et al. 2014a).

The amendments of organic matter, such as cellulose, cattle manure, rice straw, urine, dried distiller grain, and clover, have shown the substantial enhancement of As volatilization, respectively (Edvantoro et al. 2004; Mestrot et al. 2009; Mestrot et al. 2011a; Huang et al. 2012a, b; Jia et al. 2013b). It is quite popular to return rice straw into paddy fields in China, and rice straw has been proved to be effective in eliciting As volatilization compared to other organic matters such as cow dung (Mestrot et al. 2011a). The application of biochar into agricultural fields offers a number of benefits such as increasing fertility, improving soil structure, and providing a better habitat for microorganisms (Glaser et al. 2002; Lehmann et al. 2003;
Lehmann and Rondon 2006), and decreased the emission of greenhouse gases (Spokas et al. 2009; Novak et al. 2010). A few studies have dealt with the impact of biochar amendment on As mobility and transfer in the plant-soil system (Hartley et al. 2009; Namgay et al. 2010; Zheng et al. 2012). However, there is no report on the effects of biochar on As volatilization.

Arsenic volatilization and remediation efficiency could be improved via inoculation of bacteria into soil. The remarkable enhancement of As volatilization in contaminated soil slurries was observed by inoculating a new strain (Cytophagaceae) with an As methyltransferase gene (arsM) (Huang et al. 2016). Liu et al. successfully expressed an $\operatorname{ars} M$ gene in Bacillus idriensis and Sphingomonas desiccabilis accelerating As volatilization from arseniferous soil (Liu et al. 2011). However, the capacity of As volatilization by natural bacteria is limited. Inoculation of genetically engineered bacteria might be a good option for As remediation via biovolatilization. The $\operatorname{ars} M$, which is responsible for As methylation and volatilization (Qin et al. 2009; Yin et al. 2011; Lomax et al. 2012), has been successfully overexpressed in Pseudomonas putida KT2440 through synthetic biological tool. This genetic engineered P. putida KT2440 (GE P. putida) showed high activity of As volatilization (Chen et al. 2013, 2014). However, no information is available on the As volatilization by these genetically engineered bacteria in different soils.

In the present study, we chose GE P. putida as exogenous strain for bioaugmentation and rice straw (RS) or biochar (BC) as the major substrate for biostimulation to enhance the rate of As methylation and volatilization in three paddy soils. The objectives of the experiments were to (i) determine the effects of RS and $\mathrm{BC}$ amendment on As volatilization and (ii) evaluate the efficiency of As volatilization through the inoculation of the GE P. putida.

\section{Materials and methods}

\section{Preparation of materials and paddy soil}

Three different paddy soils were collected from the plowing layer $(0-20 \mathrm{~cm})$ in Dayu, Jiangxi Province, and Zhuzhou and Qiyang, Hunan Province, in southern China, respectively. All soils were air-dried, passed through a 2-mm sieve, and stored in the dark before use.

RS was air-dried and ground with a mortar to powder. BC was obtained from dried and milled rice straw by pyrolysis at $500{ }^{\circ} \mathrm{C}$ in the absence of oxygen in Muffle furnace (Vulcan31750, Neytech, USA) for $4 \mathrm{~h}$ (Fellet et al. 2011).

The GE P. putida KT2440 was cultured in a 500-mL flask containing $200 \mathrm{~mL} \mathrm{LB}$ medium $(5 \mathrm{~L})$ at $30^{\circ} \mathrm{C}$ on the shaker $(150 \mathrm{rpm})$ for 2 days with optical density at $600 \mathrm{~nm}\left(\mathrm{OD}_{600}\right)$ at about 0.8 and harvested by centrifugation $(8000 \times g$ for 
$10 \mathrm{~min}$ ). The pellets from $5 \mathrm{~L}$ culture medium were resuspended with $600 \mathrm{~mL}$ sterile deionized water.

\section{Experiments of As volatilization}

The apparatus used for trapping volatile As in the laboratory consisted of a ground Erlenmeyer flask $(250 \mathrm{~mL})$ attached to a pressure pump and a trapping tube through platinum-cured silicone tubing (Mestrot et al. 2009; Huang et al. 2012a, b). A total of $150 \mathrm{~g}$ of air-dried soil were placed into each flask, with the amendment of $5 \% \mathrm{RS}$ or $5 \% \mathrm{BC}(w / w)$ in combination with or without the inoculation of $15 \mathrm{~mL}$ resuspended bacterial solution and homogenized by hand. The number of inoculated bacteria was about $6.7 \times 10^{8}$ cell $/ \mathrm{g}$ soil by calculation based on the estimate $\left(10^{9}\right.$ cells $/ \mathrm{mL}$ for $\left.\mathrm{OD}_{600}=1.0\right)$ (Crawford et al. 2012). The non-amended soil was used as a control. The flasks inoculated with $15 \mathrm{~mL}$ resuspended bacterial solution were supplemented with $135 \mathrm{~mL}$ deionized water per flask, and others with the addition of $150 \mathrm{~mL}$ deionized water (about 2$3 \mathrm{~cm}$ layer of standing water). There were triplicate samples for each treatment. All treatments for each soil were as follows:

1. Soil (150 $\mathrm{mL}$ deionized water),

2. Soil $+\mathrm{BC}$ (applied 5\% biochar and $150 \mathrm{~mL}$ deionized water),

3. Soil $+\mathrm{RS}$ (applied 5\% rice straw and $150 \mathrm{~mL}$ deionized water),

4. Soil + GE P. putida (inoculated $15 \mathrm{~mL}$ of GE $P$. putida solution and $135 \mathrm{~mL}$ deionized water),

5. Soil $+\mathrm{BC}+\mathrm{GE}$ P. putida, and

6. Soil + RS + GE P. putida.

The flasks were air-tight with ground glass stoppers equipped with air inlet and outlet tubes. Polytetrafluoroethylene filters (0.22 $\mu \mathrm{m}$, Millipore, USA) were placed on outlets and inlets to minimize possible interference from dust in air. The inlet tube was attached to an air pump (Bldxbly, 3-W power). The trapping tube containing $2 \mathrm{~g}$ of silica gel beads was wrapped in aluminum foil to prevent illumination by ambient light and connected to the outlet tube. The silica gel beads were preimpregnated with $\mathrm{AgNO}_{3}$ as described by Mestrot et al. (2009) with a little modification. Briefly, silica gel (1.0-1.5 mm) was kept in $5 \% \mathrm{HNO}_{3}$ overnight, washed with ultrapure water (Millipore Milli-Q), impregnated with $6 \% \mathrm{AgNO}_{3}$ solution ( $\left.w / v\right)$ overnight, and then oven-dried at $70{ }^{\circ} \mathrm{C}$ to constant weight.

The filtered air was circulated through the flask at a flow rate of $3 \mathrm{~L} / \mathrm{min}$ at intervals $(8 \mathrm{~h}$ ) for $30 \mathrm{~min}$ each time. The flasks were weighed every day; deionized water was added if necessary to maintain the water content. All apparatus were arranged in a completely randomized design in the laboratory at room temperatures $\left(25^{\circ} \mathrm{C}\right)$. This experiment lasted for 3 months and the trapping tubes were replaced monthly with new ones to avoid the inactivation of $\mathrm{AgNO}_{3}$ by reducing gas generated in flask or sunlight. At the end of this experiment, soils were sampled from each flask for extraction of water-soluble As, which is the most active, mobile, and available fractions.

\section{Sample preparation and chemical analysis}

\section{Volatile arsenic}

The silica gel in each trapping tube was taken out, homogenized, and divided into two parts. One part was put into $50-\mathrm{mL}$ polyethylene tubes with $2 \mathrm{~mL}$ concentrated nitric acid, and kept overnight, and then all samples were digested in a microwaver (MARS, Matthew Inc., USA) (Sun et al. 2010). The digested samples were diluted to $50 \mathrm{~mL}$ with ultrapure water. The supernatant were filtered by a $0.45-\mu \mathrm{m}$ filter (Millipore) and stored at $4{ }^{\circ} \mathrm{C}$ until analysis. For quality control, three blanks were prepared at the same time. The concentrations of total As were determined by inductively coupled plasma mass spectrometry (ICP-MS; 7500, Agilent Technologies).

A subset of the samples with high As content was analyzed for As speciation using the other parts of the silica gel. The silica gel was eluted with water and extracted in the same microwave digestion system. The extraction program was as mentioned above. Concentrated $\mathrm{H}_{2} \mathrm{O}_{2}(0.2 \mathrm{~mL})$ was added to oxidize $\mathrm{As}(\mathrm{III})$ to $\mathrm{As}(\mathrm{V})$ due to the close retention times of TMAO and $\mathrm{As}$ (III) from the chromatographic column. Volatile arsine $\left(\mathrm{AsH}_{3}\right), \mathrm{AsH}_{2}\left(\mathrm{CH}_{3}\right), \mathrm{AsH}\left(\mathrm{CH}_{3}\right)_{2}$, and $\mathrm{As}\left(\mathrm{CH}_{3}\right)_{3}$ were quantitatively converted to monomethylarsonic acid (MMAs(V)), dimethylarsinic acid (DMAs(V)), and trimethylarsine oxide (TMAsO) during the trapping or digesting process (Mestrot et al. 2009). Arsenic species in the samples were quantified by high performance liquid chromatography-inductively coupled plasma mass spectrometry (HPLC-ICP-MS; 7500, Agilent Technologies) as previously described (Zhu et al. 2008). Indium (In) was used as an internal standard and all samples were randomized prior to analysis. Arsenic $\left(\mathrm{As}^{75}\right)$ and indium isotopes and selenium isotopes $\mathrm{Se}^{77}, \mathrm{Se}^{78}$, and $\mathrm{Se}^{82}$ were measured simultaneously to monitor possible polyatomic argon chloride interferences; no polyatomic interference was observed in all samples. A PRP-X100 10- $\mu$ m anion exchange column $(250 \times 4.1 \mathrm{~mm})$ (Hamilton, China) connected to a precolumn was used. The mobile phase was a mixture of $10 \mathrm{mM}$ diammonium hydrogenphosphate $\left(\left(\mathrm{NH}_{4}\right)_{2} \mathrm{HPO}_{4}\right)$ and $10 \mathrm{mM}$ ammonium nitrate $\left(\mathrm{NH}_{4} \mathrm{NO}_{3}\right)$, adjusted to $\mathrm{pH} 6.2$ using nitric acid. The mobile phase was pumped through the column isocratically at $1 \mathrm{~mL} / \mathrm{min}$ and the injection volume was $100 \mu \mathrm{L}$. Arsenic species in the samples were identified by comparing their retention time with the standards, and quantified by external calibration curves with peak areas.

\section{Water-soluble arsenic}

Soil samples collected from each flask at the end of the trapping of volatile As were dried and accurately weighed into a 
polypropylene centrifuge tube $(1 \mathrm{~g}, 50 \mathrm{~mL})$. Thirty milliliters of double-distilled water was added to each tube and shaken for $16 \mathrm{~h}$. The supernatant was obtained by centrifugation (3000 rpm) for $15 \mathrm{~min}$ and filtered through a $0.45-\mu \mathrm{m}$ filter (Shiowatana et al. 2001).

\section{Soil properties}

The contents of $\mathrm{C}$ and $\mathrm{N}$ in soils were detected on an element analyzer (Vario EL III, Elementar, Germany). Particle size distribution was determined using Mastersizer 3000 laser particle size analyzer. The $\mathrm{pH}$ of soils was measured with a digital $\mathrm{pH}$ meter in deionized water using a 1:2.5 $(w / w)$ ratio. The $\mathrm{pH}$ of biochar and rice straw was determined in a soil/water ratio 1:20 (w/v) following Cheng and Lehmann (2009). The content of organic matter $(\mathrm{OM})$ in soil was measured by the $\mathrm{K}_{2} \mathrm{Cr}_{2} \mathrm{O}_{7}$ oxidation-reduction titration method. Dissolved organic carbon (DOC) was determined by a total organic carbon analyzer (Liquic TOC, Elementar, Germany).

Soils were digested by AIM-500 Block Digester for determination of total $\mathrm{As}, \mathrm{Cd}, \mathrm{Pb}$, and $\mathrm{Zn}$ concentrations. Briefly, soil samples $(0.25 \mathrm{~g})$ were weighed into block digestion tubes $(100 \mathrm{~mL})$ with $5 \mathrm{~mL}$ aqua regia $\left(\mathrm{HCl}: \mathrm{HNO}_{3} 3: 1 v / v\right)$ and kept overnight, and heated at $120^{\circ} \mathrm{C}$ for $12 \mathrm{~h}$. Then, concentrated $\mathrm{HClO}_{4}(2 \mathrm{~mL})$ was injected to each tube, heated at $140{ }^{\circ} \mathrm{C}$ for $24 \mathrm{~h}$. The cooled digests were diluted to $50 \mathrm{~mL}$ with ultrapure water and filtered. For quality control, three blanks and three samples of SRM for soil (GBW07405) were prepared at the same time. The concentrations of $\mathrm{As}, \mathrm{Pb}$, and $\mathrm{Zn}$ were analyzed by inductively coupled plasma optical emission spectrometry (ICP-OES), and the $\mathrm{Cd}$ concentration was analyzed by ICP-MS.

\section{Statistical analysis and quality control}

One-way analysis of variance (ANOVA) using Tukey's test was used to identify significant differences $(P<0.05)$, while Pearson correlations were used to check the relationship between different parameters. Statistical analyses were carried out using SPSS version 16.0 software. The recoveries of As and $\mathrm{Cd}$ for soil were 104 and $118 \%$, respectively. To assess the column recovery, the recovery of the sum of species compared to the total As was within $90-110 \%$.

\section{Results}

\section{Soils and amendments}

The three soils varied widely in total As concentrations with $16.4 \mathrm{mg} / \mathrm{kg}$ (Zhuzhou), $40.3 \mathrm{mg} / \mathrm{kg}$ (Dayu), and $47.8 \mathrm{mg} / \mathrm{kg}$ (Qiyang), respectively (Table 1). The corresponding watersoluble As concentrations were $0.30 \mathrm{mg} / \mathrm{kg}$ (Zhuzhou), $0.73 \mathrm{mg} / \mathrm{kg}$ (Dayu), and $0.37 \mathrm{mg} / \mathrm{kg}$ (Qiyang), accounting for $1.8,1.8$, and $0.8 \%$ of total As concentration in these soils. Soil $\mathrm{pH}$ varied from 4.8 to 6.2 . DOC of the three soils was relatively low $(60-100 \mathrm{mg} / \mathrm{kg})$. RS and BC used in this study as exogenous $\mathrm{OM}$ showed a low As concentration at 1.3 and $0.8 \mathrm{mg} / \mathrm{kg}$, respectively. The $\mathrm{BC}$ has higher $\mathrm{pH}$ but much lower DOC levels than these of RS (Table 1).

\section{Assessment of As volatilization from As-contaminated soil}

We measured As concentration in each trapping tube and deduced the averaged flux during 3-month experiment. The fluxes of As volatilization in different soils are quite different with $0.04 \mu \mathrm{g} / \mathrm{kg} /$ year in Zhuzhou soil, $0.55 \mu \mathrm{g} / \mathrm{kg} /$ year in Qiyang soil, and $1.11 \mu \mathrm{g} / \mathrm{kg} /$ year in Dayu soil (Fig. 1). The addition of RS $(5 \% \mathrm{w} / \mathrm{w})$ significantly enhanced As volatilization from the paddy soils. The flux of As volatilization with rice straw was hundreds of times higher than corresponding non-amended soil (control). The high flux of arsines from paddy soils in the presence of rice straw was observed in Dayu soil (195.9 $\mu \mathrm{g} / \mathrm{kg} /$ year), which was much higher than that in Qiyang soil $(66.1 \mu \mathrm{g} / \mathrm{kg} / \mathrm{year})$ and Zhuzhou soil $(30.6 \mu \mathrm{g} / \mathrm{kg} /$ year). The amendment of biochar $(5 \% \mathrm{w} / \mathrm{w})$ alone also showed some positive effect on As volatilization although not significant (Qiyang).

Genetic engineered P. putida KT2440 bearing ars $M$ gene exhibited high capacity of As volatilization in previous experiments (Chen et al. 2013, 2014). The inoculation of GE P. putida KT2440 in soils improved the As volatilization but not significantly except for Zhuzhou soil. The As flux in soil with inoculation of GE P. putida KT2440 was in the range of $0.40-1.64 \mu \mathrm{g} / \mathrm{kg} / \mathrm{year}$, a bit higher than that of control $(0.04$ $1.11 \mu \mathrm{g} / \mathrm{kg} /$ year). The combined inoculation of BC or RS with bacteria into the soil was used to investigate As volatilization. In the treatment of $\mathrm{BC}+\mathrm{GE} P$. putida, only the Dayu soil showed a significant stimulation, up to $39.6 \mu \mathrm{g} / \mathrm{kg} /$ year, which was much higher than non-amended soil $(1.11 \mu \mathrm{g} / \mathrm{kg} / \mathrm{year})$, BC amendment alone $(2.18 \mu \mathrm{g} / \mathrm{kg} / \mathrm{year})$, and GE P. putida amendment alone (1.64 $\mu \mathrm{g} / \mathrm{kg} /$ year) (Fig. 1a). With the application of rice straw and GE P. putida, arsine fluxes were also the highest in Dayu soil $(483.2 \mu \mathrm{g} / \mathrm{kg} / \mathrm{year})$, followed by Zhuzhou soil (79.3 $\mu \mathrm{g} / \mathrm{kg} / \mathrm{year})$ and Qiyang soil $(29.3 \mu \mathrm{g} /$ $\mathrm{kg} /$ year). The combination of RS + GE P. putida significantly enhanced the As flux in different soils except Qiyang soil, which is lower than RS amendment alone (Fig. 1b).

The application of rice straw (soil + RS and soil + RS + GE P. putida) resulted in high rates of As volatilization. These samples were analyzed for As speciation. $\mathrm{As}\left(\mathrm{CH}_{3}\right)_{3}$ was proved to be dominant As species (65.9-84.2\%), followed by $\mathrm{AsH}_{3}(14.1-30.7 \%)$ (Fig. 2). Tiny amount of $\mathrm{AsH}\left(\mathrm{CH}_{3}\right)_{2}$ $(0-1.8 \%)$ and $\mathrm{AsH}_{2}\left(\mathrm{CH}_{3}\right)(0-3.4 \%)$ were detected as well. Inoculated GE P. putida alone slightly (but not significantly) increased the percentage of methylarsines, and reduced the percentage of inorganic arsine $\left(\mathrm{AsH}_{3}\right)$ in total volatilized As, 
Table 1 Characteristics of soils and organic amendments

\begin{tabular}{|c|c|c|c|c|c|}
\hline \multirow[t]{2}{*}{ Parameters } & \multicolumn{3}{|l|}{ Soils } & \multicolumn{2}{|c|}{ Organic amendments } \\
\hline & Dayu & Qiyang & Zhuzhou & Biochar & Rice straw \\
\hline Soil classification & Silt loam & Silt & Silt loam & - & - \\
\hline Sand (\%) & 25.4 & 10.2 & 33.4 & - & - \\
\hline Silt (\%) & 70.2 & 81.4 & 61.6 & - & - \\
\hline Clay (\%) & 4.3 & 8.3 & 5 & - & - \\
\hline $\mathrm{pH}$ & 5.86 & 6.18 & 4.83 & 10.3 & 5.64 \\
\hline $\mathrm{OM}(\%)$ & 1.9 & 3.2 & 2.8 & 22.1 & 24.4 \\
\hline DOC (mg/kg) & $66.2 \pm 9.1$ & $94.7 \pm 11.2$ & $61.9 \pm 4.3$ & $41.8 \pm 4.6$ & $2113.5 \pm 45.4$ \\
\hline Total C (\%) & 1.0 & 2.3 & 1.4 & 43.6 & 39.9 \\
\hline Total N (\%) & 0.1 & 0.3 & 0.2 & 1.7 & 1.0 \\
\hline As (mg/kg) & $40.3 \pm 0.4$ & $47.8 \pm 3.2$ & $16.4 \pm 2.0$ & $0.78 \pm 0.09$ & $1.39 \pm 0.10$ \\
\hline $\mathrm{Cd}(\mathrm{mg} / \mathrm{kg})$ & $0.78 \pm 0.02$ & $1.32 \pm 0.01$ & $4.06 \pm 0.14$ & $0.24 \pm 0.01$ & $0.15 \pm 0.00$ \\
\hline $\mathrm{Pb}(\mathrm{mg} / \mathrm{kg})$ & $52.5 \pm 1.5$ & $41.2 \pm 0.7$ & $909.1 \pm 8.9$ & $8.00 \pm 0.05$ & $0.97 \pm 0.03$ \\
\hline $\mathrm{Zn}(\mathrm{mg} / \mathrm{kg})$ & $196.0 \pm 1.7$ & $168.0 \pm 4.2$ & $1463.2 \pm 51.3$ & - & - \\
\hline Water-soluble As $(\mathrm{mg} / \mathrm{kg})$ & $0.73 \pm 0.02$ & $0.37 \pm 0.02$ & $0.30 \pm 0.04$ & - & - \\
\hline
\end{tabular}

The value was mean $\pm \mathrm{SE}$ and $n=3$ which is reasonable due to high capacity of As methylation and volatilization of GE P. putida (Chen et al. 2013, 2014). These results confirm the fact that $\mathrm{As}\left(\mathrm{CH}_{3}\right)_{3}$ is the dominant final product of As methylation, as shown in previous studies (Woolson 1977; Mestrot et al. 2009, 2011a). The production of $\mathrm{AsH}_{3}$ has also been observed (Cheng and Focht 1979; Meyer et al. 2007; Yuan et al. 2010; Mestrot et al. 2011a), and the amendment of rice straw into soils could improve $\mathrm{AsH}_{3}$ production (Mestrot et al. 2011a). Arsine is highly toxic as a hemolytic toxicant (Pakulska and Czerczak 2006; Gbaruko et al. 2008). Even low concentration $\left(32 \mathrm{mg} / \mathrm{m}^{3}\right)$ exposure may exert a hazardous or lethal effect (Pakulska and Czerczak 2006). Process for in situ removing arsine from gas should be considered with adsorbents such as cuprous oxide (Quinn et al. 2006; Petit et al. 2010).

\section{Effects of amendments on water-soluble As}

The water-soluble As in these soils was tested as bioavailable As to investigate its possible relationship with volatile As (Fig. 3). The water-soluble As concentration was 450$4000 \mu \mathrm{g} / \mathrm{kg}$, and it was obvious that the levels in Dayu (738$3765 \mu \mathrm{g} / \mathrm{kg}$ ) and Qiyang soils (494-3942 $\mu \mathrm{g} / \mathrm{kg}$ ) were much higher than that in Zhuzhou soil (450-1589 $\mu \mathrm{g} / \mathrm{kg}$ ) (Fig. 3a-c). Obviously, the amendments of RS, BC, and bacterial inoculation significantly enhanced As solubility in all kinds of soils. For each of the three soils, the treatment of RS with strain exhibited the highest water-soluble As, followed by the treatment of RS. These results showed similar trends with As volatilization, which showed highest As volatile flux in the treatment of RS and/or RS + GE P. putida (Fig. 1).
In the water-soluble As, inorganic As is the major As species and methylated As were minor $(<5 \%)$ in the nonamended or BC amended soil. Although the percents of methylated As have increased in other treatments (amended with RS or inoculated GE P. putida) in comparison with control, inorganic As was still predominant As species $(>50 \%)$. The treatment of RS + GE P. putida in Qiyang soil is an exception with the percents of methylated As up to $79 \%$ (Fig. 3d-f). Most of the organic As are DMAs(V) and tiny amount of $\operatorname{MMAs}(\mathrm{V})$ was detected, while TMAO was not detected. With the inoculation of GE $P$. putida into soil, the As concentration and percentage of methylated As in the solution were generally higher than those without inoculation treatments. There was no clear relationship between methylated As in the water solution and the volatile methylarsines, but a positive correlation $(P<0.01)$ was observed between As(III) or inorganic As in the solution and the amount of volatile $\mathrm{AsH}_{3}$ (Fig. 4). It is known that As(III) methylation and subsequent volatilization is a strictly biological process and driven by microbial activity through successive reduction and methylation (Bentley and Chasteen 2002; Turpeinen and Pantsar 2002; Qin et al. 2006). $\mathrm{AsH}_{3}$ can be formed under anoxic conditions, but the mechanism is still unknown (Cheng and Focht 1979; Pakulska and Czerczak 2006; Meyer et al. 2007; Yuan et al. 2010).

\section{Discussion}

Arsenic methylation and volatilization in situ, which can be enhanced through biostimulation and bioaugmentation, is considered as the perspective approach to soil remediation (Wang 

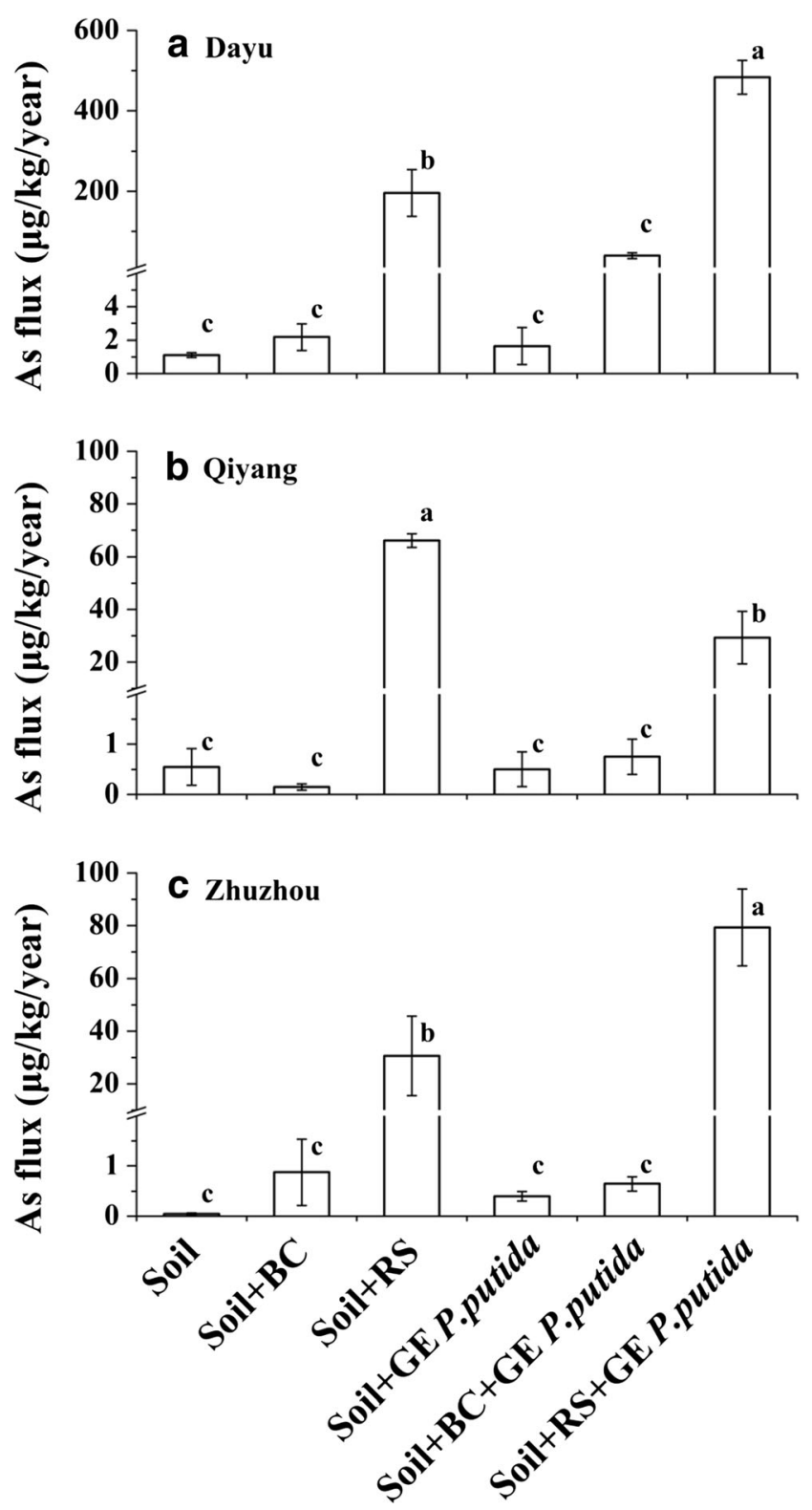

Fig. 1 Flux of volatilized As during the whole period $(n=3)$. Error bars represent the standard error based on three distinct samples. $B C 5 \%$ of biochar amendment, $R S 5 \%$ of rice straw amendment. GE P. putida Pseudomonas putida KT2440 was endowed by the Rhodopseudomonas palustris arsM (RparsM) gene. The value was mean $\pm \mathrm{SE}$ and $n=3$

et al. 2014a). In Dayu soil, As volatilization was significantly increased, much higher than that in Qiyang and Zhuzhou soils. Our results showed that soil type is a very important factor influencing As methylation and the removal from soil via volatilization (Table 2). Arsenic volatilization flux was highly related to water-soluble As, its species, or clay. Indigenous microorganisms are major contributor for As volatilization. Studies have shown wide difference of As methylation and volatilization in different soils (Mestrot et al. 2009). These are possibly due to different soil properties, the abundance, biodiversity, and activity of microorganisms responsible for As

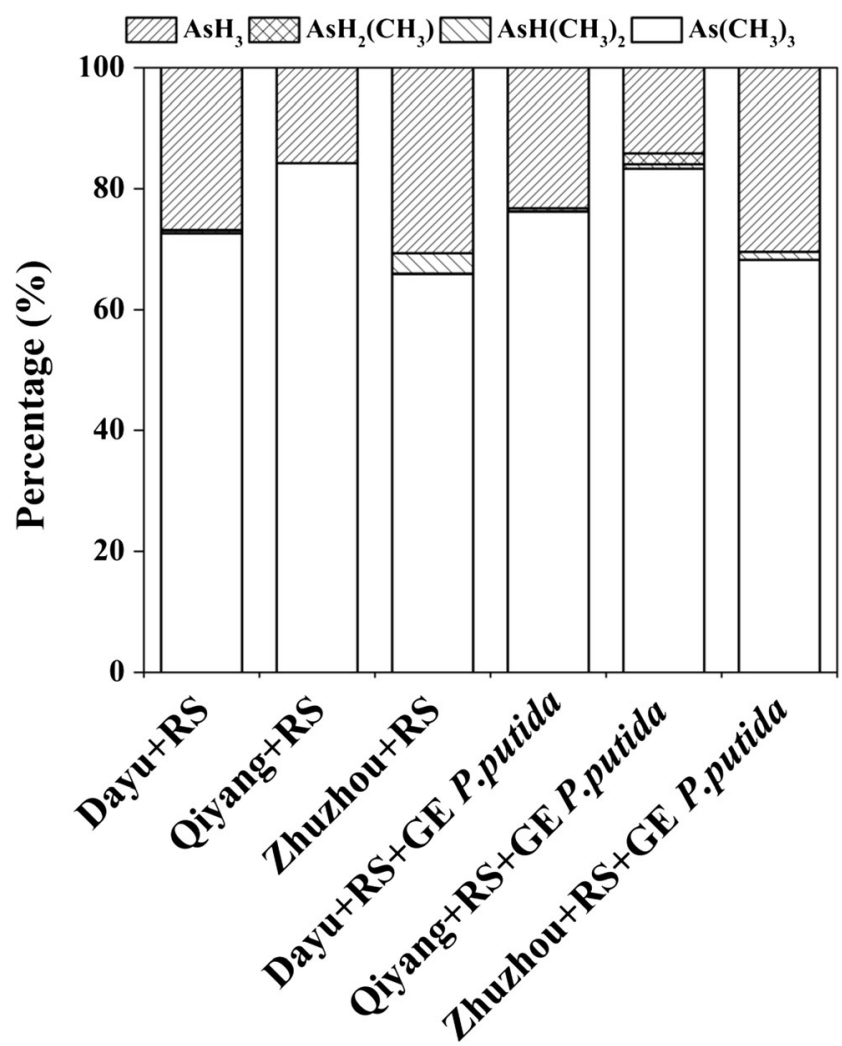

Fig. 2 Speciation of the volatilized arsenic in three different paddy soils amended with rice straw, non-inoculated or inoculated GE $P$. putida, expressed as the percentage of the sum of all species $(n=3)$

volatilization in the different paddy soils (Akins and Lewis 1976; Sanford and Klein 1988; Rhine et al. 2005; Huang et al. 2011; Mestrot et al. 2011a; Chen et al. 2014).

Rice straw addition significantly increased As methylation and volatilization from the investigated paddy soil with a percentage of $0.14-0.49 \%$ per year, consistent with previous studies (Mestrot et al. 2011a; Jia et al. 2013a, b) and higher than the results treated with cattle manure, clover, or dried distiller grain (0.07-0.16\%) (Mestrot et al. 2011a; Huang et al. 2012a, b). The decomposition of amended RS would introduce large amounts of low molecular weight organic acids into soils, including many functional groups such as $-\mathrm{COOH}$, phenol, catechol, and - $\mathrm{OH}$ (Zheng et al. 2013). These groups lead to the increase of As solubility and bioavailability, which was supported by previous reports (Jia et al. 2013a, b; Wang et al. 2016), though competing with negatively charged As for adsorption sites (Redman et al. 2002; Weng et al. 2009). The increase of bioavailable As might be one possible explanation for stimulation of As volatilization. In addition, RS could serve as an energy source to support the growth of indigenous heterotrophic microbes, including As methylaters which facilitate As methylation and volatilization (Mestrot et al. 2009; Solaiman et al. 2009; Thomas et al. 2010; Huang et al. 2012a, b; Jia et al. 2013a, b). 
Fig. 3 Arsenic concentration in water solution in paddy soil from a Dayu, b Qiyang, and c Zhuzhou and amended with rice straw (RS) or biochar (BC), inoculated GE P. putida $(n=3)$. Arsenic speciation in extractable solution at the end of the incubation experiment, d Dayu, e Qiyang, and f Zhuzhou soils $(n=3)$, expressed as the percentage of the sum of all species. Error bars represent the standard error based on three distinct samples

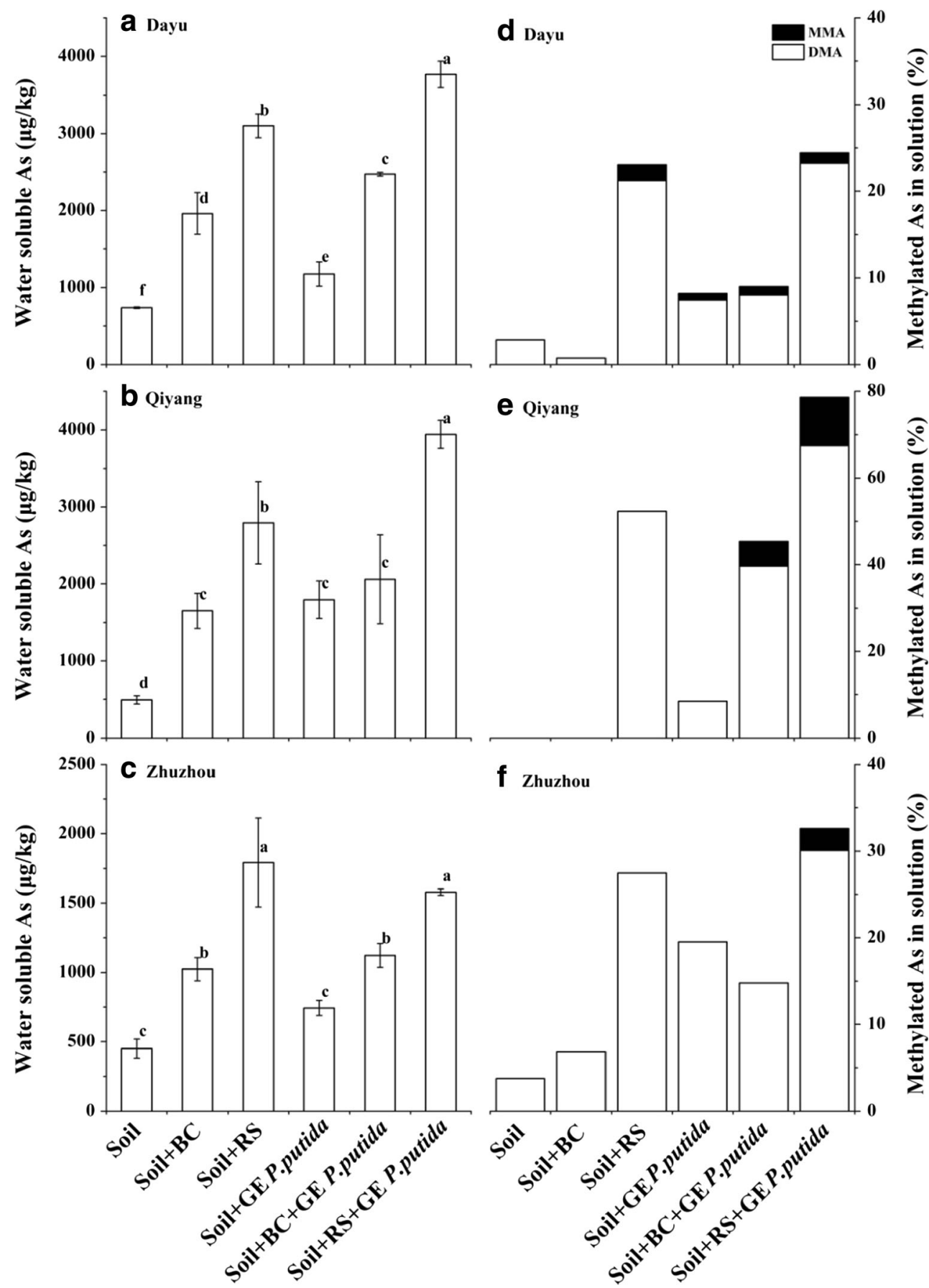

Biochar addition in paddy soils significantly increased As bioavailability (Fig. 3), which was similar to the significant increase of As concentration in pore water (Zheng et al. 2012, 2015). Biochar addition in soil increased the abundance of Fereducing bacteria. The increase of copy numbers in respiratory As reducing $(\operatorname{arr} A)$ and detoxifying reducing genes $(\operatorname{ars} C)$ suggested microbial reduction of $\mathrm{As}(\mathrm{V})$ adsorbed on Fe minerals to As(III) and increase of As release (Wang et al. 2016). It was acceptable to believe that the inoculation of GE P. putida in soil significantly increased the concentration of water-soluble As
(Fig. 3). Because P. putida KT2440 has been reported to bear arsenate reductase gene $(\operatorname{ars} C)$ in its chromosome and rapidly reduce $\mathrm{As}(\mathrm{V})$ to $\mathrm{As}(\mathrm{III})$ in soil (Chen et al. 2013, 2014).

The GE P. putida have exhibited a high capacity for As methylation and volatilization in As-contaminated soil (Chen et al. 2014). When the GE P. putida was inoculated alone or combined with $\mathrm{BC}$, the bioaugmentation effect on As volatilization was not significantly improved. The GE P. putida is the aerobic bacteria and needs oxygen for growth, but the flooded paddy soils are oxygen limited and $\mathrm{BC}$ contains a 


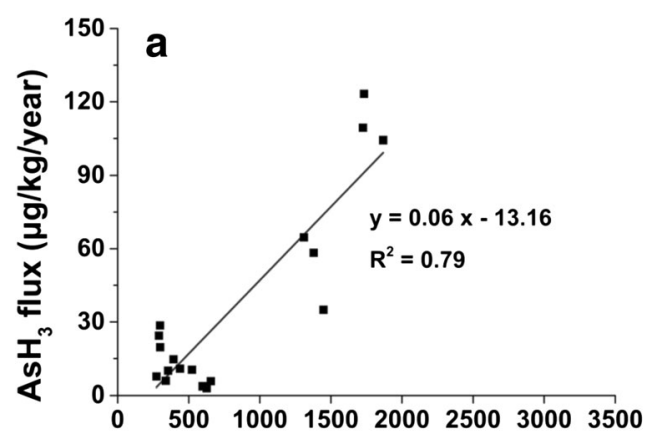

Soluble inorganic As(III) $(\mu \mathrm{g} / \mathrm{kg})$

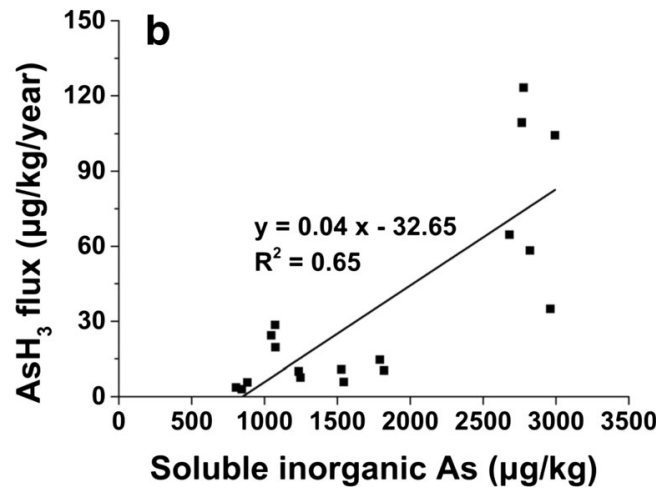

Fig. 4 Relationship between the observed volatile fluxes of $\mathrm{AsH}_{3}$ and the concentrations of $\mathbf{a}$ As(III) and $\mathbf{b}$ inorganic As in extractable solution in three different paddy soils amended with rice straw, non-inoculated or inoculated GE $P$. putida, $(n=3)$ little labile nutrients (Beesley et al. 2011, 2013). Thus, the relatively low nutrients and oxygen limit the bacterial growth and As volatilization. Besides, low As bioavailability in soil constraints the ability of As methylation and volatilization by GE $P$. putida.

Rice possesses unique characteristics in rice root by excreting oxygen and oxidants into the rhizosphere to form an oxidizing microenvironment (Liu et al. 2006; Huang et al. 2012a, b). P. putida KT2440 belongs to rhizobacteria that has the capacity to colonize a wide range of plants. P. putida KT2440 would be colonized on the rice root or in the rhizospheric soil. The accumulation of inorganic As in rice grain would be reduced because of the decreased level of inorganic As in rhizosphere via As volatilization or methylation of GE P. putida KT2440.

In comparison with soil + RS in Qiyang soil, the As flux of soil + RS + GE P. putida was decreased (Fig. 1b). It seemed that the presence of GE P. putida did not enhance As removal, like other two soils. The Qiyang soil has higher silt and clay content (silt, 81.4\%; clay, 8.3\%) than those in other soils (Dayu, 70.2 and 4.3\%; Zhuzhou, 61.6 and 5.0\%, respectively) (Table 1), which means that the Qiyang soil tends to have higher soil compaction and lower gas permeability than other soils (Jenkinson 1981; Groffman and Tiedje 1991). Although much methylated As was exerted in the presence of GE P. putida in the treatment of soil + RS + GE P. putida, relatively poor soil permeability limited the emission of gaseous As from Qiyang soil (Fig. 1b) and relatively more methylated

Table 2 Correlation analysis of original soil data, water-soluble As in the soil samples after experiments, and $\mathrm{As}, \mathrm{As}\left(\mathrm{CH}_{3}\right)_{3}$, and $\mathrm{AsH} \mathrm{H}_{3}$ flux in the treatment of soil + RS + GE P. putida

\begin{tabular}{|c|c|c|c|c|c|c|c|c|c|c|c|c|c|}
\hline & Sand & Silt & Clay & $\mathrm{pH}$ & DOC & As & RWSA & RAs(III) & RAs(V) & WSA & As flux & $\begin{array}{l}\mathrm{As}\left(\mathrm{CH}_{3}\right)_{3} \\
\text { flux }\end{array}$ & $\begin{array}{l}\mathrm{AsH}_{3} \\
\text { flux }\end{array}$ \\
\hline Sand & 1 & & & & & & & & & & & & \\
\hline Silt & $-0.992 * *$ & 1 & & & & & & & & & & & \\
\hline Clay & $-0.808 * *$ & $0.725^{*}$ & 1 & & & & & & & & & & \\
\hline $\mathrm{pH}$ & $-0.888^{* *}$ & $0.921 * *$ & 0.530 & 1 & & & & & & & & & \\
\hline DOC & $-0.866^{* *}$ & $0.823 * *$ & $0.862 * *$ & $0.702 *$ & 1 & & & & & & & & \\
\hline As & $-0.875^{* *}$ & $0.899 * *$ & 0.558 & $0.994 * *$ & $0.727^{*}$ & 1 & & & & & & & \\
\hline RWSAs $^{\mathrm{a}}$ & 0.023 & 0.078 & -0.488 & 0.427 & -0.249 & 0.419 & 1 & & & & & & \\
\hline RWSAs(III) ${ }^{\mathrm{b}}$ & 0.121 & -0.020 & -0.562 & 0.341 & -0.318 & 0.336 & $0.993 * *$ & 1 & & & & & \\
\hline $\operatorname{RWSAs}(V)^{\mathrm{c}}$ & -0.040 & 0.142 & -0.437 & 0.480 & -0.202 & 0.469 & $0.997 * *$ & $0.981 * *$ & 1 & & & & \\
\hline $\mathrm{WSA}^{\mathrm{d}}$ & $-0.801 * *$ & $0.850 * *$ & 0.385 & $0.983 * *$ & 0.613 & $0.976^{* *}$ & 0.564 & 0.484 & 0.611 & 1 & & & \\
\hline As flux & 0.275 & -0.178 & -0.659 & 0.192 & -0.428 & 0.192 & $0.958 * *$ & $0.980 * *$ & $0.937 * *$ & 0.341 & 1 & & \\
\hline $\begin{array}{l}\mathrm{As}\left(\mathrm{CH}_{3}\right)_{3} \\
\text { flux }\end{array}$ & 0.253 & -0.156 & -0.643 & 0.214 & -0.410 & 0.214 & $0.963 * *$ & $0.983 * *$ & $0.943 * *$ & 0.362 & $1.000 * *$ & 1 & \\
\hline $\mathrm{AsH}_{3}$ flux & 0.344 & -0.249 & $-0.706^{*}$ & 0.119 & -0.487 & 0.119 & $0.938 * *$ & $0.966 * *$ & $0.912 * *$ & 0.271 & $0.997 * *$ & $0.995 * *$ & 1 \\
\hline
\end{tabular}

$* P<0.05, * * P<0.01$

${ }^{\text {a }}$ Water-soluble As in original soils

${ }^{\mathrm{b}}$ Water-soluble As(III) in original soils

${ }^{\mathrm{c}}$ Water-soluble As(V) in original soils

${ }^{\mathrm{d}}$ Water-soluble As in soil samples at the end of experiments 
As was kept in water ( $\sim 80 \%$; Fig. $3 b)$ than other soil (25$35 \%$ ). This is one plausible reason for low As volatilization in Qiyang soil.

Nutrients are enhanced in these soils in the presence of rice straw, which substantially support the bacterial growth, including GE P. putida (Mestrot et al. 2009). This may explain why the high efficiency of volatilizing As in the inoculated GE P. putida soil amended with RS. The levels of As flux of soil + RS + GE P. putida in Dayu soil $(483.2 \mu \mathrm{g} / \mathrm{kg} /$ year $)$ were much higher than that in Qiyang soil $(29.3 \mu \mathrm{g} / \mathrm{kg} / \mathrm{year})$ and Zhuzhou soil ( $79.3 \mu \mathrm{g} / \mathrm{kg} / \mathrm{year})$. This may be attributed by the relatively high water-soluble As concentration in soil (Table 1) (Rhine et al. 2005; Mestrot et al. 2011a; Chen et al. 2014).

The highest As flux $(483.2 \mu \mathrm{g} / \mathrm{kg} /$ year$)$ was observed in the Dayu soil in the presence of RS and GE P. putida, with annual As volatilization of $1.2 \%$, much higher than reported results (Edvantoro et al. 2004; Mestrot et al. 2011a; Huang et al. 2012a, b). These can be developed and applied to manipulate As biovolatilization, both for bioremediation and mitigating the health risks of As accumulated in food crops.

\section{Conclusions}

In summary, biostimulation with rice straw amendment and bioaugmentation with GE $P$. putida KT2440 inoculation are potentially feasible strategies for As volatilization and removal in some kinds of agricultural soil. Arsenic emission was significantly enhanced from these paddy soils amended with $5 \%$ rice straw or inoculated with the GE P. putida. The combination of genetically engineered bacteria with rice straw addition exhibited the highest efficiency of As volatilization $(483.2 \mu \mathrm{g} / \mathrm{kg} /$ year $)$ and could be a promising strategy for bioremediation processes of As-contaminated environments.

Acknowledgements This project was financially supported by the Natural Science Foundation of China (Nos. 41371459, 41501336, 41501336), the State Key Program of Natural Science Foundation of China (No. 41330853), the National High Technology Research and Development Program of China (863 Program, 2013AA06A209), and Beijing Outstanding Talent Training Project (2015000020060G141).

\section{References}

Akins MB, Lewis RJ (1976) Chemical distribution and gaseous evolution of arsenic-74 added to soils as DSMA-74As. Soil Sci Soc Am J 40: $655-658$

Akter KF, Owens G, Davey DE, Naidu R (2005) Arsenic speciation and toxicity in biological systems. Rev Environ Contam Toxicol 184: 97-149

Beesley L, Moreno-Jimenez E, Gomez-Eyles JL, Harris E, Robinson B, Sizmur T (2011) A review of biochars' potential role in the remediation, revegetation and restoration of contaminated soils. Environ Pollut 159:3269-3282
Beesley L, Marmiroli M, Pagano L, Pigoni V, Fellet G, Fresno T, Vamerali T, Bandiera M, Marmiroli N (2013) Biochar addition to an arsenic contaminated soil increases arsenic concentrations in the pore water but reduces uptake to tomato plants (Solanum lycopersicum L.) Sci Total Environ 454:598-603

Bentley R, Chasteen TG (2002) Microbial methylation of metalloids: arsenic, antimony, and bismuth. Microbiol Mol Biol Rev 66:250-271

Brown S, Chaney RL, Hallfrisch JG, Xue Q (2003) Effect of biosolids processing on lead bioavailability in an urban soil. J Environ Qual 32:100-108

Challenger F (1945) Biological methylation. Chem Rev 36:315-361

Chen J, Qin J, Zhu YG, Lorenzo VD, Rosen BP (2013) Engineering the soil bacterium Pseudomonas putida for arsenic methylation. Appl Environ Microbiol 79:4493-4495

Chen J, Sun GX, Wang XX, Lorenzo VD, Rosen BP, Zhu YG (2014) Volatilization of arsenic from polluted soil by Pseudomonas putida engineered for expression of the ars $M$ arsenic(III) S-adenosine methyltransferase gene. Environ Sci Technol 48:10337-10344

Cheng CN, Focht DD (1979) Production of arsine and methylarsines in soil and in culture. Appl Environ Microbiol 38:494-498

Cheng CH, Lehmann J (2009) Ageing of black carbon along a temperature gradient. Chemosphere 75:1021-1027

Crawford JM, Portmann C, Zhang X, Roeffaers MBJ, Clardy J (2012) Small molecule perimeter defense in entomopathogenic bacteria. Proc Natl Acad Sci U S A 109:10821-10826

Cullen WR, Bentley R (2005) The toxicity of trimethylarsine: an urban myth. J Environ Monit 7:11-15

Cullen WR, Reimer KJ (1989) Arsenic speciation in the environment. Chem Rev 89:713-764

Edvantoro BB, Naidu R, Megharaj M, Merrington G, Singleton I (2004) Microbial formation of volatile arsenic in cattle dip site soils contaminated with arsenic and DDT. Appl Soil Ecol 25:207-217

Feldmann J, Devalla S, Raab A, Hansen HR, Hirner AV, Emons H (2004) Analytical strategies for arsenic speciation in environmental and biological samples. In: Hirner AV, Emons H (Eds) Organic metal and metalloid species in the environment: analysis, distribution, processes and toxicological evaluation. Springer, New York, pp 41-70

Fellet G, Marchiol L, Delle Vedove G, Peressotti A (2011) Application of biochar on mine tailings: effects and perspectives for land reclamation. Chemosphere 83:1262-1267

Gao S, Burau RG (1997) Environmental factors affecting rates of arsine evolution from and mineralization of arsenicals in soil. J Environ Qual 26:753-763

Gbaruko BC, Ana G, Nwachukwu JK (2008) Ecotoxicology of arsenic in the hydrosphere: implications for public health. Afr J Biotechnol 7: 4737-4742

Glaser B, Lehmann J, Zech W (2002) Ameliorating physical and chemical properties of highly weathered soils in the tropics with charcoal-a review. Biol Fertil Soils 35:219-230

Gong Z, Lu X, Ma M, Watt C, Le XC (2002) Arsenic speciation analysis. Talanta 58:77-96

Groffman PM, Tiedje JM (1991) Relationship between denitrification, $\mathrm{CO}_{2}$ production and air filled porosity in soils of different texture and drainage. Soil Biol Biochem 23:299-302

Hartley W, Dickinson NM, Riby P, Lepp NW (2009) Arsenic mobility in brownfield soils amended with green waste compost or biochar and planted with Miscanthus. Environ Pollut 157:2654-2662

Huang JH, Hu KN, Decker B (2011) Organic arsenic in the soil environment: speciation, occurrence, transformation, and adsorption behavior. Water Air Soil Pollut 219:401-415

Huang H, Zhu YG, Chen Z, Yin XX, Sun GX (2012a) Arsenic mobilization and speciation during iron plaque decomposition in a paddy soil. J Soils Sediments 12:402-410 
Huang H, Jia Y, Sun GX, Zhu YG (2012b) Arsenic speciation and volatilization from flooded paddy soils amended with different organic matters. Environ Sci Technol 46:2163-2168

Huang K, Chen C, Zhang J, Tang Z, Shen QR, Rosen BP, Zhao FJ (2016) Efficient arsenic methylation and volatilization mediated by a novel bacterium from an arsenic-contaminated paddy soil. Environ Sci Technol 50:6389-6396

Jenkinson D S. 1981. The fate of plant and animal residues in soil. In: Greenland DS, Hayes MHB (Eds) The Chemistry of Soil Processes. John Wiley, New York, pp. 505-601

Jia Y, Huang H, Zhong M, Wang FH, Zhang LM, Zhu YG (2013a) Microbial arsenic methylation in soil and rice rhizosphere. Environ Sci Technol 47:3141-3148

Jia Y, Sun GX, Huang H, Zhu YG (2013b) Biogas slurry application elevated arsenic accumulation in rice plant through increased arsenic release and methylation in paddy soil. Plant Soil 365:387-396

Lehmann J, Rondon M (2006) Bio-char soil management on highly weathered soils in the humid tropics biological approaches to sustainable soil systems. CRC Press, Boca Raton, pp 517-530

Lehmann J, Silva JPD, Steiner C, Nehls T, Zech W, Glaser B (2003) Nutrient availability and leaching in an archaeological Anthrosol and a Ferralsol of the central Amazon basin: fertilizer, manure and charcoal amendments. Plant Soil 249:343-357

Liao HC, Chu YJ, Su YC, Hsiao SY, Wei CC, Liu CW, Liao CM, Shen WC, Chang FJ (2011) Arsenite-oxidizing and arsenate-reducing bacteria associated with arsenic-rich groundwater in Taiwan. J Contam Hydrol 123:20-29

Liu WJ, Zhu YG, Hu Y, Williams PN, Gault AG, Meharg AA, Charnock JM, Smith FA (2006) Arsenic sequestration in iron plaque, its accumulation and speciation in mature rice plants (Oryza sativa L). Environ Sci Technol 40:5730-5736

Liu S, Zhang F, Chen J, Sun GX (2011) Arsenic removal from contaminated soil via biovolatilization by genetically engineered bacteria under laboratory conditions. J Environ Sci 23:1544-1550

Lomax C, Liu WJ, Wu L, Xue K, Xiong J, Zhou J, Mcgrath SP, Meharg AA, Miller AJ, Zhao FJ (2012) Methylated arsenic species in plants originate from soil microorganisms. New Phytol 193:665-672

Mestrot A, Uroic MK, Plantevin T, Islam MR, Krupp EM, Feldmann J, Meharg AA (2009) Quantitative and qualitative trapping of arsines deployed to assess loss of volatile arsenic from paddy soil. Environ Sci Technol 43:8270-8275

Mestrot A, Feldmann J, Krupp EM, Hossain MS, Romanross G, Meharg AA (2011a) Field fluxes and speciation of arsines emanating from soils. Environ Sci Technol 45:1798-1804

Mestrot A, Merle JK, Broglia A, Feldmann J, Krupp EM (2011b) Atmospheric stability of arsine and methylarsines. Environ Sci Technol 45:4010-4015

Mestrot A, Planer-Friedrich B, Feldmann J (2013) Biovolatilisation: a poorly studied pathway of the arsenic biogeochemical cycle. Environ Sci Proc Impacts 15(9):1639-1651

Meyer J, Schmidt A, Michalke K, Hensel R (2007) Volatilisation of metals and metalloids by the microbial population of an alluvial soil. Syst Appl Microbiol 30:229-238

Namgay T, Singh B, Singh BP, Krull E, Singh B, Joseph S (2010) Influence of biochar application to soil on the availability of As, $\mathrm{Cd}, \mathrm{Cu}, \mathrm{Pb}$, and $\mathrm{Zn}$ to maize (Zea mays L). Aust J Soil Res 48: 638-647

Novak JM, Busscher WJ, Watts DW, Laird DA, Ahmedna MA, Niandou MAS (2010) Short-term $\mathrm{CO}_{2}$ mineralization after additions of biochar and switchgrass to a Typic Kandiudult. Geoderma 154:281-288

Pakulska D, Czerczak S (2006) Hazardous effects of arsine: a short review. Int J Occup Med Environ Health 19:36-44

Petit C, Peterson GW, Mahle J, Bandosz TJ (2010) The effect of oxidation on the surface chemistry of sulfurcontaining carbons and their arsine adsorption capacity. Carbon 48:1779-1787
Qin J, Rosen BP, Zhang Y, Wang GJ, Franke S, Rensing C (2006) Arsenic detoxification and evolution of trimethylarsine gas by a microbial arsenite S-adenosylmethionine methyltransferase. Proc Natl Acad Sci U S A 103:2075-2080

Qin J, Lehr CR, Yuan CG, Le XC, McDermott TR, Rosen BP (2009) Biotransformation of arsenic by a Yellowstone thermoacidophilic eukaryotic alga. Proc Natl Acad Sci U S A 106:5213-5217

Quinn R, Dahl TA, Diamond BW, Toseland BA (2006) Removal of arsine from synthesis gas using a copper on carbon adsorbent. Ind Eng Chem Res 45(18):6272-6278

Redman AD, Macalady DL, Ahmann D (2002) Natural organic matter affects arsenic speciation and sorption onto hematite. Environ Sci Technol 36:2889-2896

Rhine ED, Garcia-Dominguez E, Phelps CD, Young LY (2005) Environmental microbes can speciate and cycle arsenic. Environ Sci Technol 39:9569-9573

Sanford RA, Klein DA (1988) Environmental bioremediation for organometallic compounds: microbial growth and arsenic volatillization from soil and retorted shale. Appl Organomet Chem 2:159-169

Shiowatana J, McLaren RG, Chanmekha N, Samphao A (2001) Fractionation of arsenic in soil by a continuous-flow sequential extraction method. J Environ Qual 30(6):1940-1949

Solaiman ARM, Meharg AA, Gault AG, Charnock JM (2009) Arsenic mobilization from iron oxyhydroxides is regulated by organic matter carbon to nitrogen $(\mathrm{C}: \mathrm{N})$ ratio. Environ Int 35:480-484

Spokas KA, Koskinen WC, Baker JM, Reicosky DC (2009) Impacts of woodchip biochar additions on greenhouse gas production and sorption/degradation of two herbicides in a Minnesota soil. Chemosphere 77:574-581

Sun GX, Lu XA, Williams PN, Zhu YG (2010) Distribution and translocation of selenium from soil to grain and its speciation in paddy rice (Oryza sativa L). Environ Sci Technol 44:6706-6711

Thomas JE, Rhue RD (1997) Volatilization of arsenic in contaminated cattle dipping vat soil. Bull Environ Contam Toxicol 59:882-887

Thomas B, Ruben K, Andreas K, Philippe Van C, Matthew GV, Andreas V, Kate C (2010) Biogeochemical redox processes and their impact on contaminant dynamics. Environ Sci Technol 44:15-23

Turpeinen R, Pantsar M (2002) Role of microbes in controlling the speciation of arsenic and production of arsines in contaminated soils. Sci Total Environ 285:133-145

Wang PP, Sun GX, Jia Y, Meharg AA, Zhu YG (2014a) A review on completing arsenic biogeochemical cycle: microbial volatilization of arsines in environment. J Environ Sci 26:371-381

Wang PP, Sun GX, Zhu YG (2014b) Identification and characterization of arsenite methyltransferase from an archaeon, Methanosarcina acetivorans C2A. Environ Sci Technol 48:12706-12713

Wang PP, Bao P, Sun GX (2015) Identification and catalytic residues of the arsenite methyltransferase from a sulfate-reducing bacterium, Clostridium sp BXM. FEMS Microbiol Lett 362:1-8

Wang HY, Wen SL, Chen P, Zhang L, Cen K, Sun GX (2016) Mitigation of cadmium and arsenic in rice grain by applying different silicon fertilizers in contaminated fields. Environ Sci Pollut Res 23:3781-3788

Weng LP, Van Riemsdijk WH, Hiemstra T (2009) Effects of fulvic and humic acids on arsenate adsorption to goethite: experiments and modeling. Environ Sci Technol 43:7198-7204

Woolson EA (1977) Generation of alkylarsines from soil. Weed Sci 25: $412-416$

Yin XX, Chen J, Qin J, Sun GX, Rosen BP, Zhu YG (2011) Biotransformation and volatilization of arsenic by three photosynthetic cyanobacteria. Plant Physiol 156:1631-1638

Yuan CG, Zhang KG, Wang ZH, Jiang GB (2010) Rapid analysis of volatile arsenic species released from lake sediment by a packed cotton column coupled with atomic fluorescence spectrometry. J Anal At Spectrom 25:1605-1611 
Zheng RL, Cai C, Liang JH, Huang Q, Chen Z, Huang YZ, Arp HPH, Sun GX (2012) The effects of biochars from rice residue on the formation of iron plaque and the accumulation of $\mathrm{Cd}, \mathrm{Zn}, \mathrm{Pb}, \mathrm{As}$ in rice (Oryza sativa $\mathrm{L}$ ) seedlings. Chemosphere 89:856-862

Zheng RL, Sun GX, Zhu YG (2013) Effects of microbial processes on the fate of arsenic in paddy soil. Chin Sci Bull 58:186-193

Zheng RL, Chen Z, Cai C, Tie BQ, Liu XL, Reid BJ, Huang Q, Lei M, Sun GX, Baltrènaite E (2015) Mitigating heavy metal accumulation into rice (Oryza sativa L) using biochar amendment - a field experiment in Hunan, China. Environ Sci Pollut Res 22:11097-11108

Zhu YG, Sun GX, Lei M, Teng M, Liu YX, Chen NC, Wang LH, Carey AM, Deacon C, Raab A, Meharg AA, Williams PN (2008) High percentage inorganic arsenic content of mining impacted and nonimpacted Chinese rice. Environ Sci Technol 42:5008-5013 